\title{
ARTICLE OPEN \\ Sanitation of blackwater via sequential wetland and electrochemical treatment
}

\author{
Guruprasad V. Talekar ${ }^{1}$, Priya Sharma ${ }^{1}$, Anant Yadav ${ }^{1}$, Peter Clauwaert $\mathbb{D}^{2}{ }^{2}$, Korneel Rabaey ${ }^{2}$ and Srikanth Mutnuri ${ }^{1}$
}

The discharge of untreated septage is a major health hazard in countries that lack sewer systems and centralized sewage treatment. Small-scale, point-source treatment units are needed for water treatment and disinfection due to the distributed nature of this discharge, i.e., from single households or community toilets. In this study, a high-rate-wetland coupled with an electrochemical system was developed and demonstrated to treat septage at full scale. The full-scale wetland on average removed $79 \pm 2 \%$ chemical oxygen demand (COD), $30 \pm 5 \%$ total Kjeldahl nitrogen (TKN), $58 \pm 4 \%$ total ammoniacal nitrogen (TAN), and $78 \pm 4 \%$ orthophosphate. Pathogens such as coliforms were not fully removed after passage through the wetland. Therefore, the wetland effluent was subsequently treated with an electrochemical cell with a cation exchange membrane where the effluent first passed through the anodic chamber. This lead to in situ chlorine or other oxidant production under acidifying conditions. Upon a residence time of at least $6 \mathrm{~h}$ of this anodic effluent in a buffer tank, the fluid was sent through the cathodic chamber where pH neutralization occurred. Overall, the combined system removed $89 \pm 1 \%$ COD, $36 \pm 5 \%$ TKN, $70 \pm 2 \%$ TAN, and $87 \pm 2 \%$ ortho-phosphate. An average $5-$ log unit reduction in coliform was observed. The energy input for the integrated system was on average $16 \pm 3 \mathrm{kWh} / \mathrm{m}^{3}$, and $11 \mathrm{kWh} / \mathrm{m}^{3}$ under optimal conditions. Further research is required to optimize the system in terms of stability and energy consumption.

npj Clean Water (2018)1:14; doi:10.1038/s41545-018-0014-x

\section{INTRODUCTION}

For the majority of the world, there exists inadequate wastewater collection and treatment to enable safe transport of the wastewater from industrial and domestic sources to a centralized sewage treatment facility. This absence leads to discharge of untreated, contaminated wastewater into water bodies. For example, a 2015 study estimated that in India, 62\% of the total sewage was discharged directly into nearby water bodies. ${ }^{1}$ Worldwide, it was estimated that almost one-fifth of all urban citizens (over 700 million people) live without an effective toilet, among which 100 million people practice open defecation and 600 million people rely on toilets that do not fulfill minimum requirements of hygiene, safety, or privacy. ${ }^{2}$ It is further estimated that $37.4 \%$ of India's urban population lack access to safe, private toilets. $^{2}$ Even in those areas that have toilets, the untreated/ partially treated wastewater makes its way, to local water bodies causing a variety of water pollution problems. Inadequate and unsafe discharge of untreated domestic/municipal wastewater has resulted in contamination of $75 \%$ of all surface water across India. ${ }^{3}$ In urban India, $37 \%$ of human excreta generated are unsafely disposed, imposing significant effects on public health, loss of working days, and environmental costs, which results in loss of national revenues. ${ }^{3}$ The cost of inadequate sanitation for India was estimated as $\$ 54$ billion or $6.4 \%$ of the country's GDP in $2006 .{ }^{4}$

Distributed water contamination from septage, i.e., from a network of septic tanks, can be counteracted with decentralized treatments. The technology proposed in this study, constructed wetlands with the subsurface flow, have evolved towards direct treatment technology for domestic wastewater in the last few decades. ${ }^{5}$ The operational and maintenance costs of wetlands are low when compared to conventional treatment systems as they require low or almost no energy input. ${ }^{5}$ These wetlands are demonstrably effective, with a $\log _{10}$ reduction in bacteria (recorded at $0.5-3){ }^{6}$ A key drawback of constructed wetlands is the inconsistency in pathogen removal efficiency between different types of wetlands, between wetlands of the same design and between runs on same wetlands. ${ }^{7-9}$ Discharge from wetlands tends to require additional treatment. Disinfection of water can be achieved with oxidants, chlorination (chlorine, hypochlorite) and ozonization. ${ }^{10,11}$ Disinfection chemicals, chlorine, and other oxidants (hypochlorite and hypochlorous acid) can be electrochemically produced in-situ by oxidation of the chloride indigenously present in the wastewater by using dimensionally stable anodes. ${ }^{12}$ This prevents the need for supply and storage of such chemicals. Electrochemical treatment has also been shown to lower the Biological oxygen demand (BOD), chemical oxygen demand (COD), and nitrogen concentration, ${ }^{13}$ and has been extensively described for industrial and domestic wastewater for a variety of purposes, including electrocoagulation, electrooxidation, electrodisinfection, electroflotation, and electrosorption. ${ }^{13-23}$

In this study, we demonstrate a second stage constructed wetland with the vertical subsurface flow in tandem with an electrochemical cell (EC). The EC contains a cation exchange membrane (CEM) to separate flow between the cathode and anode chambers. In the anode chamber, the acidic conditions (5-6) and chlorination effectively disinfects the septage. ${ }^{24,25}$ This novel concept for decentralized wastewater treatment for households and community toilets was developed to treat septic tank

\footnotetext{
${ }^{1}$ Applied Environmental Biotechnology Laboratory, Department of Biological Sciences, Birla Institute of Technology and Science, K K Birla Goa Campus, NH 17 B, Zuarinagar 403 726 Goa, India and ${ }^{2}$ Center for Microbial Ecology and Technology, Department of Biotechnology, Ghent University, Ghent, Belgium

Correspondence: Srikanth Mutnuri (srikanth@goa.bits-pilani.ac.in)
}

Received: 26 January 2018 Revised: 26 May 2018 Accepted: 31 May 2018

Published online: 16 August 2018 
Table 1. Charge requirement for electrolysis to achieve desired $\mathrm{pH}$ gradient and percentage reduction of parameters during batch and continuous lab scale experiments

\begin{tabular}{llllll}
\hline Parameters & $\begin{array}{l}\text { Anodic passage } \\
\left(\mathrm{A}_{\text {batch }}\right)\end{array}$ & $\begin{array}{l}\text { Cathodic passage } \\
\left(C_{\text {batch }}\right)\end{array}$ & $\begin{array}{l}\text { Anode to cathode } \\
\text { passage }\left(A C_{\text {batch }}\right)\end{array}$ & $\begin{array}{l}\text { Cathode to anode } \\
\text { passage }\left(C A_{\text {batch }}\right)\end{array}$ & $\begin{array}{l}\text { Anode to cathode } \\
\text { passage }\left(A C_{\text {Cont }}\right)\end{array}$ \\
\hline $\begin{array}{l}\text { Charge density } \\
\text { (Coulombs/L) } \\
\text { pH }\end{array}$ & 2880 & 2826 & 2262 & 3086 & 4500 \\
$\begin{array}{l}\text { Percentage of reduction } \\
\text { COD }\end{array}$ & $2.72 \pm 0.03$ & $10.22 \pm 0.03$ & $8.43 \pm 0.05$ & $6.43 \pm 0.03$ & $9 \pm 0.2$ \\
TKN & $46 \pm 1 \%$ & $36 \pm 5 \%$ & $75 \pm 3 \%$ & $36 \pm 2 \%$ & $70 \pm 4 \%$ \\
TAN & $81 \pm 1 \%$ & $68 \pm 9 \%$ & $30 \pm 4 \%$ & $47 \pm 2.0 \%$ & 0 \\
ortho-P & $55 \pm 1 \%$ & $0 \pm 21 \%$ & $20 \pm 4 \%$ & $67 \pm 1 \%$ & $43 \pm 12 \%$ \\
log(CFU) & $36 \pm 2 \%$ & $69 \pm 2 \%$ & $14 \pm 3 \%$. & $47 \pm 4 \%$ & $54 \pm 3 \%$ \\
\hline
\end{tabular}
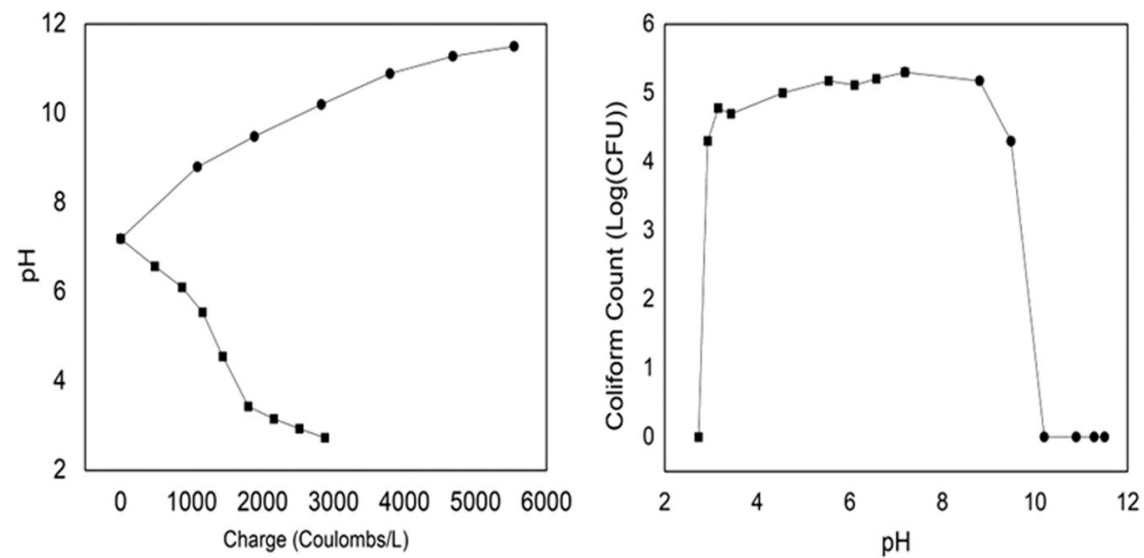

Fig. 1 Variation of anode and cathode effluent $\mathrm{pH}$ of $\mathrm{A}_{\text {batch }}(\square)$ and $C_{\text {batch }}(\mathbf{Q})$, respectively, with charge and effect of pH change on the coliform count in anode and cathode effluent of $A_{\text {batch }}(\square)$ and $C_{\text {batch }}(\boldsymbol{O})$, respectively

effluent, and laboratory, single household $(\mathrm{SHH})$ and community toilet scale.

\section{RESULTS AND DISCUSSION}

Laboratory scale trials

The purpose of the lab scale trials was to test the efficacy of the EC on real septage under different conditions of the flow path (anodic/cathodic disinfectant generation), charge per liter and residence time in holding tank.

The charge needed per volume of neutral wastewater (Table 1) to reach $\mathrm{pH}<3$ (anodic) and $\mathrm{pH}>9$ (cathodic) was established as 2880 and $2826 \mathrm{CL}^{-1}$ (Coulomb per liter) in anodic passage $\left(A_{\text {batch }}\right)$ and cathodic passage $\left(C_{\text {batch }}\right)$, respectively (Fig. 1$)$. The target $\mathrm{pH}$ was obtained after 70 and $15 \mathrm{~min}$ for $A_{\text {batch }}$ and $C_{\text {batch, }}$ respectively (Table ST1 \& ST2). Electrochemical oxidation of water at the anode resulted in oxygen and proton production, with reduction of water at the cathode results in hydrogen gas and hydroxide ions. Protons and other cations migrate through the CEM in order to close the circuit. The presence of the cation selective membrane was crucial to obtain the $\mathrm{pH}$ gradient. With respect to disinfection, a $\log _{10}$ reduction in the coliform count in both anode effluent and cathode effluent was observed at $\mathrm{pH}<$ 2.7 and $\mathrm{pH}>10.2$, measured at a count of $5.0 \pm 0.8$ (Fig. 1). This implies that passage through anode $\left(A_{\text {batch }}\right)$ or cathode $\left(C_{\text {batch }}\right)$ can have a similar outcome.

The coliform disinfection observed in the septage at $\mathrm{pH}<3$ in anolyte is most likely due to the acidic $\mathrm{pH}$ in combination with chlorine and reactive oxygen species generation. ${ }^{26,27}$ Hypochlorous acid penetrates the bacterial cell membrane and damages the bacterial cell internally. Protons destroy the amino-acid bonds in nucleic acids, dysregulate the $\mathrm{pH}$ in the cytoplasm and precipitate proteins. $^{28}$ In the catholyte, coliform removal at $\mathrm{pH}>9$ was most likely due to inactivation at alkaline conditions potentially in combination with free ammonia ( $52 \pm 4$ to $130 \pm 4 \mathrm{mg} \mathrm{NH}_{3}-\mathrm{N} / \mathrm{L}$ ).

In the anode chamber, the COD reduction was expected to occur due to direct and indirect oxidation of the organic matter at the surface of the anode and in the electrolyte. ${ }^{29,30}$ Total ammoniacal nitrogen (TAN) removal can occur due to different mechanisms. First, migration of the $\mathrm{NH}_{4}{ }^{+}$across the membrane into the cathode chamber allows volatilization as ammonia $\left(\mathrm{NH}_{3}\right)$ at a high pH (e.g., >9). ${ }^{31}$ Second, The decrease of ammonia is also possibly due to its decomposition by hypochlorite generated from chloride, to produce nitrate and nitrogen gas or/and due to partial decomposition to nitrogen by the $\mathrm{OH}$ radicals. ${ }^{32}$ Finally, ammonium reduction is also possible due to possible direct oxidation of ammonium at the $\mathrm{Ti} / \mathrm{IrO}_{2}$ and $\mathrm{Ti} / \mathrm{RuO}_{2}$ anode ${ }^{33}$ (Figure SF1). The ortho-phosphate reduction was low $(39 \pm 2 \%)$, due to sedimentation and/or adsorption at the anode surface.

In the cathode chamber, COD reduction can be associated with coagulation at higher $\mathrm{pH}$ and subsequent sedimentation. Total Kjeldahl nitrogen (TKN) reduction was due to the reduction of organic nitrogen (Figure SF2). The increase in the TAN values could be related to the release of TAN during degradation of organic nitrogen, whereas the overall decrease of TKN indicates some possible $\mathrm{NH}_{3}$ volatilization. The decrease in the orthophosphate was likely due to local precipitation in the proximity of the cathode caused by a locally high $\mathrm{pH}$, although the precipitate could not be visually/microscopically observed in these experiments. 


\begin{tabular}{|c|c|c|c|c|c|c|}
\hline Parameters & \multicolumn{3}{|l|}{$A C_{\text {batch }}$} & \multicolumn{3}{|l|}{$C A_{\text {batch }}$} \\
\hline COD & $900 \pm 10$ & $264 \pm 32$ & $264 \pm 32$ & $835 \pm 16$ & $811 \pm 20$ & $535 \pm 16$ \\
\hline TKN & $280 \pm 0$ & $175 \pm 10$ & $196 \pm 9$ & $256 \pm 5$ & $249 \pm 5$ & $137 \pm 5$ \\
\hline $\log (C F U)$ & 5.3 & nd & nd & 6.0 & nd & 3.7 \\
\hline
\end{tabular}

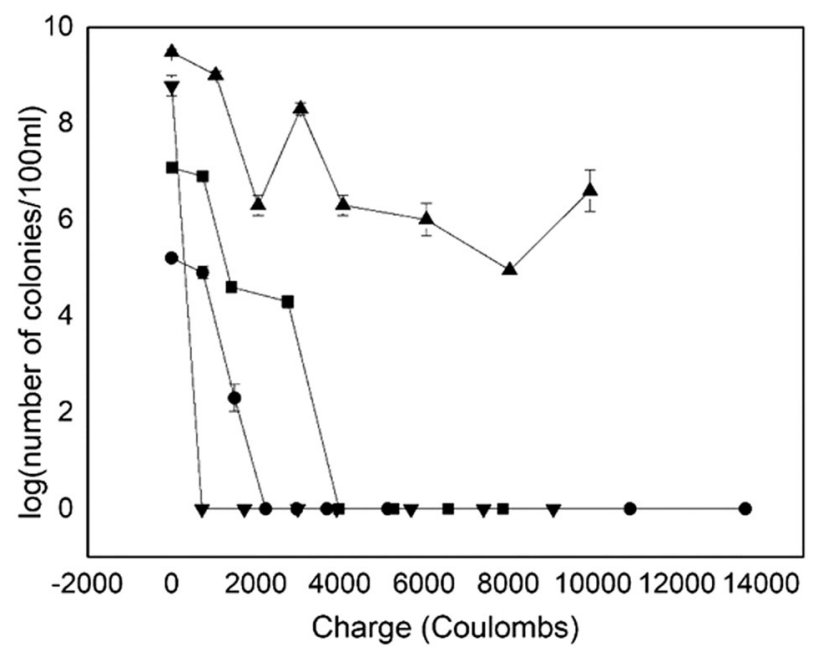

Fig. 2 Reduction in Klebsiella pneumoniae $(\square)$, Escherichia coli ( $)$, Bacillus subtilis ( $\mathbf{\Delta})$, and Staphylococcus aureus $(\boldsymbol{\nabla})$ colony count with charge

During the second phase of the batch lab scale tests, passage of the wastewater through one compartment (anode or cathode) was followed by passage through the other electrode compartment (cathode or anode) to neutralize the $\mathrm{pH}$. The amount of charge supplied to achieve the target $\mathrm{pH}$ in the anode to cathode configuration ( $\left.A C_{\text {batch }}\right)$ and cathode to anode configuration $\left(\mathrm{CA}_{\text {batch }}\right)$ was 5004 and $6171 \mathrm{CL}^{-1}$, respectively (recirculation flow rate $=0.48 \mathrm{~L} / \mathrm{h}$ ). The log reduction in coliform counts achieved by electrolysis during anode to cathode passage $\left(A C_{\text {batch }}\right)$ and cathode to anode passage ( $\left.C \mathrm{~A}_{\text {batch }}\right)$ of septage was $5.0 \pm 1.2$ and $6.0 \pm 1.0$, respectively. The energy consumption for the $A C_{\text {batch }}$ and $C A_{\text {batch }}$ mode was 28 and $35 \mathrm{Wh} \mathrm{L}^{-1}$, respectively. The higher energy investment during CA mode relates to higher precipitation leading to increased ohmic resistance. The impact on other parameters is shown in Table 1.

It was observed that $C O D$ removal in $A C_{\text {batch }}$ mode was almost double that achieved in $\mathrm{CA}_{\text {batch }}$ mode (Table 1, ST3 \& ST4), while removal in TKN, TAN, and ortho-phosphate was higher in $\mathrm{CA}_{\text {batch }}$ mode. However, the reduction of COD, TKN, and TAN occurs in the anode chamber to a greater extent than in the cathode chamber during the flow (Table 2). Hence, in order to maximize the recovery of nutrients from the disinfected septage and minimize scaling (e.g., P-precipitates), the anode to cathode passage flow pattern appears preferable. With respect to disinfection, either of the two flow patterns could be chosen as the $\log _{10}$ reduction is similar. However, anode to cathode passage flow pattern (AC) is preferable, as there exists an opportunity to hold the septage at acidic conditions $(\mathrm{pH}<3)$, at which the survival of bacteria is least $(7.5 \%)$ in comparison to survival at alkaline conditions $(\mathrm{pH}>9)$
(66.11\%). ${ }^{34}$ Additionally, the energy consumption for the anode to cathode passage flow mode is low.

Continuous electrolysis of septage $\left(\mathrm{AC}_{\text {cont }} ; 0.48 \mathrm{~L} \mathrm{~h}^{-1} ; 10.4 \mathrm{~mA} /\right.$ $\mathrm{cm}^{2}$ ) showed a reduction in COD and coliform similar to that seen in $A C_{\text {batch }}$ (Table 1). TAN and ortho-phosphate reduction were significantly higher in $A C_{\text {cont }}$ (Table 1 \& ST5) and there was no reduction in TKN.

Continuous electrolysis $\left(8-9 \mathrm{~mA} / \mathrm{cm}^{2} ; \mathrm{HRT}_{\mathrm{EC}}=0.42 \mathrm{~h}\right.$; $\mathrm{HRT}_{\text {reser- }}$ voir $=0.2 \mathrm{~h}$ ) with $\mathrm{AC}$ passage of septage inoculated with Klebsiella pneumoniae, Escherichia coli, Bacillus subtilis, and Staphylococcus aureus in separate experiments (Accont-spiked) resulted in a $\log _{10}$ reduction of $7.0 \pm 4.0,5.2 \pm 2.0$, $2.8 \pm 2.0$, and $8.8 \pm 4.0$, respectively (Fig. 2). The relatively small reduction of $B$. subtilis counts may be due to the formation of spores that are resistant to acidic conditions. ${ }^{35,36}$ The charge density at which the reduction was observed in the colonies of $K$. pneumoniae, E. coli, B. subtilis, and S. aureus was 3978, 2232, 9936, and $720 \mathrm{CL}^{-1}$, respectively. $B$. subtilis showed resistance to treatment even at higher $\mathrm{HRT}_{\mathrm{EC}}$ of 0.48 and $0.75 \mathrm{~h}$ (Figure SF3). However, the survival of $B$. subtilis through the anode to cathode passage does not hinder the choice of this flow pattern, as the septage is disinfected with respect to the coliform.

During the helminths experiments, morphological changes in the helminth eggs (loss of egg shape and cell deformation) were observed after $6 \mathrm{~h}$ in all cases. The eggs incubated in hypochlorite disinfectant (all $\mathrm{pH}$ and concentration combinations), cathode effluent and anode effluent (EChelminths) started to form globules (Fig. 3c), and the eggs content began to seep from some of the eggs (Fig. 3b2,c1,d2), indicating non-viability and decortication. Similar morphological changes were observed in the eggs incubated in septage adjusted to alkaline $\mathrm{pH}$. However, the eggs incubated in septage adjusted to acidic conditions retained their shape (Fig. 3e1,e2) even after the 10th hour of incubation. The helminth eggs were morphologically similar to the control sample indicating that only the acidic conditions of septage do not have a deteriorating effect. Hence, it appears that alkaline conditions $(\mathrm{pH}$ >9) contribute to the inactivation of eggs (i.e., eggs do not transform into mature larva and worms) while acidic conditions $(\mathrm{pH} \leq 3)$ in combination with oxidative species, such as hypochlorite, were responsible for the non-viability of the eggs. Based on these experiments, it was determined that a minimum incubation time of $6 \mathrm{~h}$ in septage subjected to anodic oxidation (acidic $\mathrm{pH}$ containing free chlorine $(0.8-1 \mathrm{mg} / \mathrm{L})$ ) is required to inactivate the helminth eggs, and thus the household and community scale (CS) reactors were designed to contain a holding/buffer tank that ensured residence of the anodic effluent for a minimum period of $6 \mathrm{~h}$. Further studies are required to quantify the extent of helminth egg inactivation.

Long-term single household field trials

In the long term (60 days), SHH field trials, continuous treatment of septage (composition in Table 3 ) was executed in $\mathrm{AC}_{\text {cont }}$ mode. 

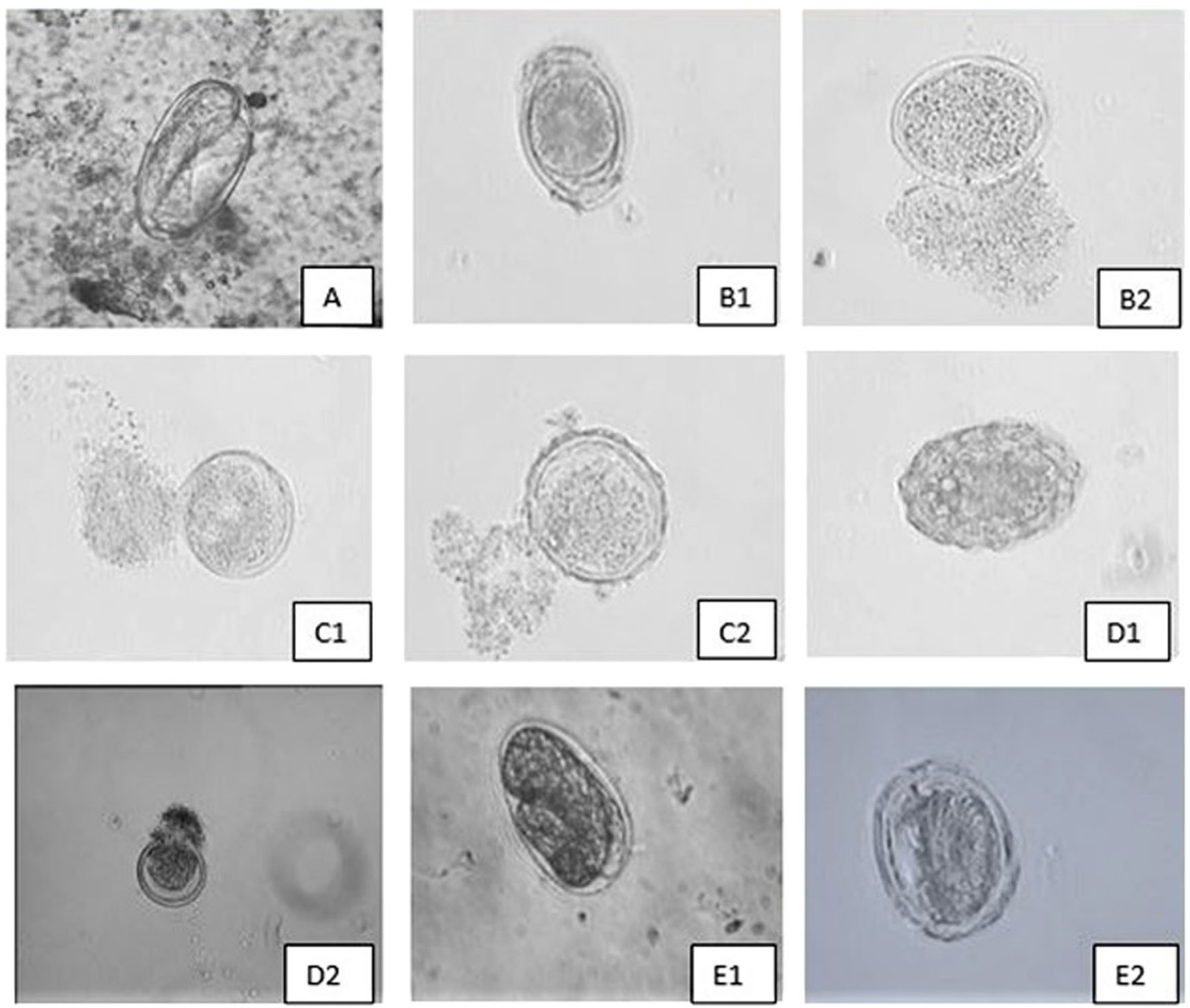

Fig. 3 Microscopic photographs (Olympus CKX53) at 40x magnification showing morphological changes in helminths. a Control; b1,b2 anode effluent of EC at 4th and 6th hour; $\mathbf{c 1 , c 2}$ cathode effluent of EC at 4th and 6th hour; d1,d2 hypochlorite solution (1.2\%) at 4th and 6th hour; $\mathbf{e 1 , e 2}$ septage adjusted to acidic $\mathrm{pH}$ at 4th and 6th hour

Table 3. Average wastewater characteristics of the influent septage used for lab scale experiments, household scale trials, and community scale trials

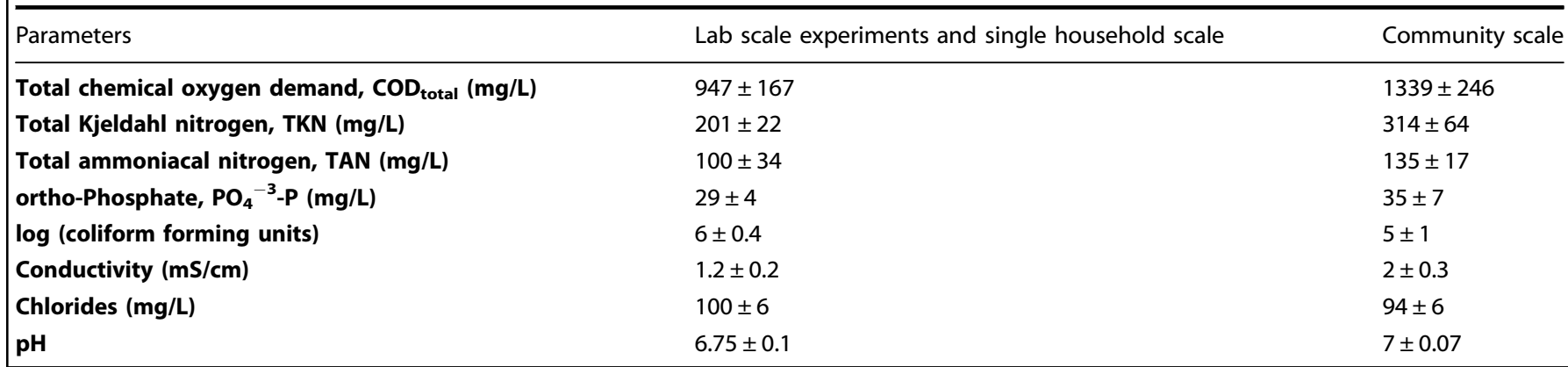

Here, the household scale electrochemical reactor showed a very low log reduction of $1.6 \pm 0.4$ in the coliform count on average over an analysis period of 12 days. A reduction in COD of $21 \pm$ $0.5 \%$ was observed vs. $70 \pm 4 \%$ in the lab scale test $\left(A C_{\text {cont }}\right.$ ) (Table 1). TAN and ortho-phosphate concentrations were both reduced for $A C_{\text {batch }}$ and $A C_{\text {cont }}$ while TKN did not decrease (Table $1 \&$ ST6). The membrane and stainless-steel cathode became clogged by calcareous deposits over time $\left(1.2 \mathrm{~g} \mathrm{Ca}^{2+} /\right.$ day $)$, and an accumulation of an organic layer at the anode side of the membrane was observed. The charge supplied and energy investment to treat $0.144 \mathrm{~m}^{3} /$ day of septage was $2712 \pm 153 \mathrm{CL}^{-1}$ and $27 \pm 4 \mathrm{kWh} / \mathrm{m}^{3}$, respectively. This indicates that the EC by itself, as deployed here, cannot achieve treatment and disinfection.

A vertical flow constructed wetland (VFCW) at $0.5 \mathrm{~m}^{2}$ P.E. was introduced between the septic tank and the electrochemical reactor to lower the organic load on the electrochemical reactor. When taking only the wetland performance into consideration, the average COD, TKN, TAN, and ortho-phosphate reduction was $77 \pm 8 \%, 51 \pm 11 \%, 85 \pm 5 \%$, and $93 \pm 4 \%$, respectively. Average log reduction in CFU was only $1 \pm 0.3$, showing the inability of a high-rate wetland to significantly decrease bacterial pathogens.

Continuous treatment of septage $\left(0.180 \mathrm{~m}^{3}\right.$ day $\left.^{-1}\right)$ by the integrated system (wetland $+E C$ in $\mathrm{AC}_{\text {cont }}$ mode with $1152 \mathrm{C}$ 


\begin{tabular}{|c|c|c|c|c|c|c|c|c|}
\hline \multirow[t]{2}{*}{ Parameters } & \multicolumn{8}{|c|}{ Average reduction observed } \\
\hline & Inflow & EC outflow & Inflow & Wetland outflow & EC outflow & Inflow & Wetland outflow & EC outflow \\
\hline TAN (mg/L) & $106 \pm 13$ & $82 \pm 45$ & $100 \pm 34$ & $16 \pm 5$ & $18 \pm 4$ & $135 \pm 17$ & $50 \pm 16$ & $36 \pm 10$ \\
\hline ortho-P (mg/L) & $20 \pm 3$ & $14 \pm 1$ & $29 \pm 4$ & $2.1 \pm 0.6$ & $0.6 \pm 0.1$ & $35 \pm 7$ & $9 \pm 3$ & $5 \pm 1$ \\
\hline $\log$ (CFU) & $6.6 \pm 0.4$ & $5 \pm 0.7$ & $6 \pm 0.4$ & $5 \pm 0.5$ & nd & $5 \pm 1$ & $3 \pm 0.5$ & $<0.67$ \\
\hline
\end{tabular}

$\mathrm{L}^{-1}$ ) showed a significant reduction in most of the wastewater parameters and disinfection (Table $4 \&$ ST7). The average decrease in COD, TKN, TAN, and ortho-phosphate concentration over a trial period of 60 days was $84 \pm 7 \%, 45 \pm 14 \%, 84 \pm 8 \%$, and $98 \pm 1 \%$, respectively for the combined treatment. All the parameters except TKN of the treated water were below the permissible limit for the water's discharge into inland surface water (Table 4). The log reduction in the coliform count was $6.0 \pm 0.4$, and the energy consumption in the EC was $16.7 \pm 3 \mathrm{kWh} / \mathrm{m}^{3}$.

The reduction in COD, TKN, TAN, and ortho-phosphate concentration is principally achieved by VFCW while disinfection occurs in the EC. In a VFCW, organic matter is retained and degraded aerobically (oxygen supplied by the plant roots) in the top layer of the filter media. ${ }^{37}$ Aerobic conditions also facilitate the nitrification of TKN and TAN to nitrate and nitrites. The nitrate and nitrites remain intact as generally there is no anaerobic conditions in the VFCW. ${ }^{38}$ Integration of VFCW with the EC reduced the organic and mineral load on the $E C$, thereby reducing the amount of calcium precipitation $\left(0.06 \mathrm{~g} \mathrm{Ca}^{2+} /\right.$ day) between the electrodes and the membrane by $59 \%$. Also, the energy investment for the long-term run decreased by $40 \%$. This reduced the frequency of removing the membrane from the reactor for washing. The membrane was cleaned once in 60 days on day 33. The reactor was effectively operated for 2 months continuously after the trial run without replacement of the membrane.

Long-term field trial at community scale

For the long-term (60 days) CS trials $\left(1.3 \mathrm{~m}^{3} /\right.$ day, $\left.3660 \pm 688 \mathrm{CL}^{-1}\right)$, a $40 \mathrm{~m}^{2}\left(0.4 \mathrm{~m}^{2} /\right.$ P.E.) second stage VFCW was constructed followed by a buffer tank, anodic treatment, holding time, and final cathodic treatment. The average COD, TKN, TAN, and orthophosphate reduction over a trial period of 60 days by the VFCW (without an EC) was $79 \pm 11 \%, 33 \pm 8 \%, 58 \pm 16 \%$, and $78 \pm 6 \%$. The log reduction of CFU was $2.0 \pm 0.6$, confirming the earlier experiments in which the high-rate VFCW did not remove coliforms. The integrated system showed average reductions of $89 \pm 12 \%, 24 \pm 10 \%, 70 \pm 10 \%$, and $85 \pm 7 \%$ of COD, TKN, TAN, and ortho-phosphate reduction, respectively (Table ST8), which is above the reductions obtained in a similar study on combination of constructed wetlands with photocatalytic ozonation, with the exception of TKN. ${ }^{39}$ Similar to the results in the SHH integrated system, only the TKN of the treated water was well above the permissible limit. Log reduction in the coliform count by the integrated system was $4.0 \pm 1$. Maximum and minimum CFU reduction of $\log 5$ and $\log 2$ was observed over a constant current range of 20-35 A (2400-4200 C L $\left.\mathrm{L}^{-1}\right)$. The residual free chlorine of the EC effluent was $0.94 \pm 0.1 \mathrm{mg} / \mathrm{L}$. The energy requirements for disinfection varied between 11 and $16 \mathrm{kWh} / \mathrm{m}^{3}\left(16 \pm 3 \mathrm{kWh} / \mathrm{m}^{3}\right)$.

The organics were mostly removed by the VFCW, similar to the $\mathrm{SHH}$ trials, while disinfection was achieved by the EC unit supporting the conclusion that EC disinfection is effective on secondary wastewater effluents, ${ }^{40}$ albeit at lower levels than observed in the $\mathrm{SHH}$ scale reactor. In the $\mathrm{EC}$, calcareous precipitates accumulated over time on the cathode side surface of the membrane while an organic charred layer formed on the anode side surface of the membrane, decreasing the current developed due to increased membrane resistance. The voltage-current behavioral data, recorded over a period of $290 \mathrm{~h}$ as shown in Figure SF4, revealed a gradual drop in the current due to increased voltage after $195 \mathrm{~h}$. This increase required cleaning of the EC approximately every 9 days. After 2 cleaning cycles, the membrane showed physical damage, in particular the detachment of the membrane polymer from the cellulosic backbone within the membrane. Whereas the cathodic fouling may be a benefit, as it will consist of inorganic precipitates including phosphates, as evidenced by the decrease in $\mathrm{P}$ in the effluent, it also caused a gradual degeneration of the membrane. The fouling on the anodic side surface of the membrane is likely due to sorption of incoming organics. It will thus be key to define operational parameters minimizing membrane damage and investigate a range of membranes. More stable operation could also lead to lower average power consumption.

The CS achieved on average a lower treatment percentage than the $\mathrm{SHH}$. The average energy requirements per $\mathrm{m}^{3}$ of wastewater treated $\left(16 \pm 3 \mathrm{kWh} / \mathrm{m}^{3}\right)$ was slightly lower for CS than for $\mathrm{SHH}$ and was as low as $11 \mathrm{kWh} / \mathrm{m}^{3}$. At present, the investment and operational costs of the $\mathrm{SHH}$ and CS systems are still high due to high energy consumption and the cost of the materials used in this research (CEM and MMO electrodes). As a result, future research will need to focus on lowering the energy costs and material costs.

In conclusion, the most effective operation was observed in the AC flow pattern through the EC during electrolysis, rather than the CA flow pattern. The former achieves a higher percentage reduction in wastewater parameters $(C O D, T K N, T A N$, and orthophosphate concentration), and achieves disinfection of coliforms and helminth eggs. The disinfection of water is due to the combined effect of acidic $\mathrm{pH}$ and the oxidative species generated at the anode during electrolysis. The minimum incubation time of septage subjected to anodic oxidation (acidic $\mathrm{pH}$ containing free chlorine $(0.8-1 \mathrm{mg} / \mathrm{L})$ ) required to inactivate the helminths eggs was $6 \mathrm{~h}$. The integrated $\mathrm{SHH}$ and CS treatment systems seem to be promising systems that can be integrated with the existing septic tank for SHHs and the community to provide water treatment and disinfection. Further optimization of the design of the CS EC reactor is needed, together with research into membrane alternatives and operational parameters for the continuous process. Although potential disinfection byproducts (DBP) need to be identified, we anticipate limited production based on earlier work by the Hoffman group ${ }^{41}$ and the fact that the applied charge in our process was considerably lower than the cases where DBPs were detected. 


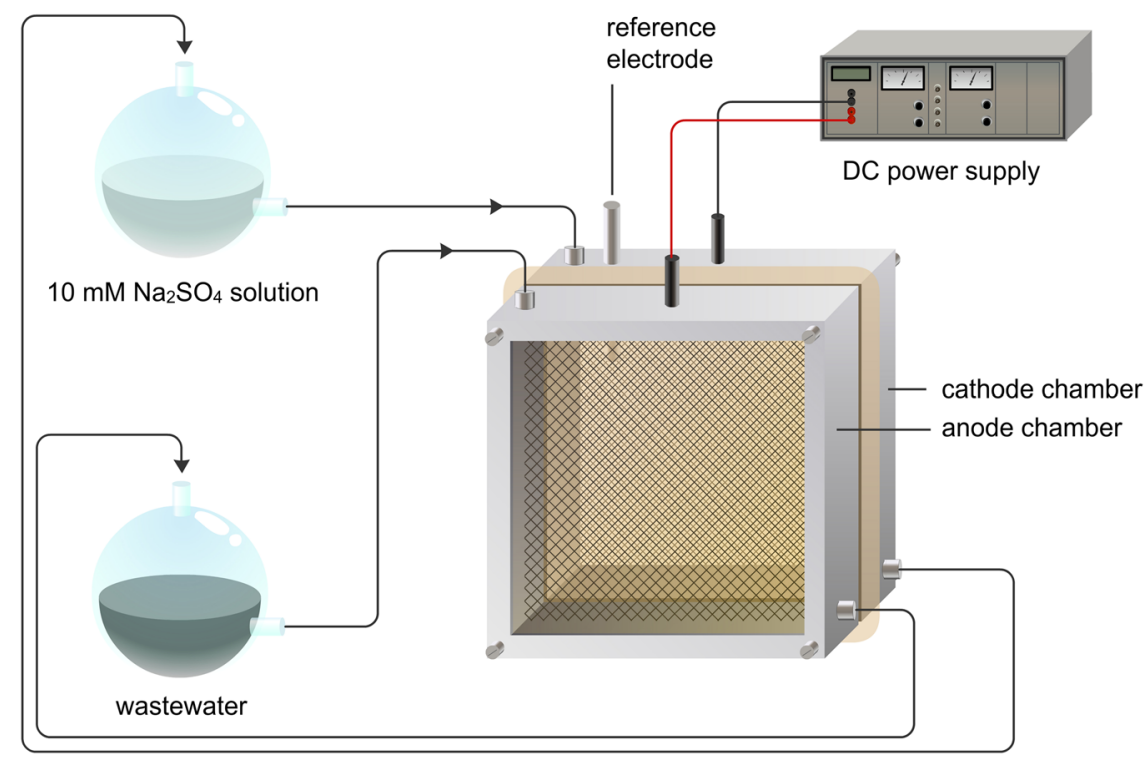

Fig. 4 Schematic representation of experimental setup showing recirculation of septage through anode chamber and salt solution through cathode chamber for run $A_{\text {batch }}$

\section{MATERIALS AND METHODS}

Influents and analysis

For the lab and household scale experiments, septage was obtained from a septic tank connected to a SHH toilet (four users) located in BITS-Pilani K K Birla Goa Campus. Sampling and analysis of septage was performed over a period of 4 months during which 25 influent samples were analyzed for COD (closed reflux, colorimetric method), TKN (macro-Kjeldahl method), total ammonia nitrogen (titrimetric method), ortho-phosphate (vanadomolybdophosphoric acid colorimetric method), chloride (Mohr's titration), free chlorine (DPD photometric method), and coliform forming units (standard total coliform fermentation technique). ${ }^{42}$

The coliform count was estimated by 10 -fold serial dilutions of the sample in saline (0.85\%). Each dilution was inoculated in MacConkey broth containing Durham tubes. The tubes were then incubated for $24-48 \mathrm{~h}$ at $44^{\circ} \mathrm{C}$. Positive tubes (showing gas production) were selected and the corresponding numbers of coliform were obtained from the most probable number (MPN) tables. As a confirmatory test, the sample from the positive tubes was plated on the MacConkey agar and EMB agar, and incubated for $24-36 \mathrm{~h}$ at $37^{\circ} \mathrm{C}$. The number of colonies were then counted.

The viability of helminth eggs prior to and after the experiment was confirmed by microscopic observation. ${ }^{43}$ The extraction of the eggs from the samples in which they were incubated was done by floatation-sedimentation method.

For full-scale deployment, the wetland was integrated to the CS septic tank $\left(6 \mathrm{~m}^{3}\right)$ located within the BITS-Pilani Goa Campus, and samples were taken once every 5 days and analyzed for the same parameters as described above.

The precipitate from the surface of the stainless-steel cathode in the EC collected after 12 days running of EC reactor alone and after 33 days running of the household scale integrated system was analyzed by SEM. SEM photos and elemental analysis was done by field emission gun scanning microscope (Quanta FEG-250) coupled with energy dispersive spectroscopy (EDAX, Ametek 174422 Smart Insight) operated at $10 \mathrm{kV}$.

\section{Laboratory scale experiments}

A plate-and-frame EC was used as described earlier. ${ }^{44}$ The anode and cathode chambers had internal dimensions of $8 \times 8 \times 2 \mathrm{~cm}^{3}$. A CEM (Ultrex CMI7000, Membranes International Inc.) was placed in between the two frames and the two frames were in turn sandwiched between two end plates. An IrOx MMO mesh $\left(8 \times 8 \mathrm{~cm}^{2}\right)$ was used as anode (Magneto, The Netherlands), stainless steel mesh (SS 316, 600 Micron, $8 \times 8 \mathrm{~cm}^{2}$ ) was used as the cathode. Power was supplied by a GPS-4303 (GW Instek) DC regulated power supply. Peristaltic pumps (Flowtech-NFP01, India) with flow rate range of $0.6-100 \mathrm{~mL} / \mathrm{min}$ were used to recirculate sample. Working volume in each chamber was $100 \mathrm{~mL}$.

Initial batch experiments. Initial experiments were executed in batch mode. First, $500 \mathrm{~mL}$ septage and $500 \mathrm{~mL}$ of $10 \mathrm{mM}$ sodium sulfate solution were recirculated through the anode chamber and cathode chamber, respectively, at a rate of $0.9 \mathrm{~L} \mathrm{~h}^{-1}$ (Fig. 4). Electrolysis was carried out at constant currents ranging from 0.064 to $1.2 \mathrm{~A}$ for $45 \mathrm{~min}$, with current doubled at each $5 \mathrm{~min}$ interval. The relationship between current and voltage was established and the development of $\mathrm{pH}$ gradient across the membrane confirmed. A similar experiment was performed with $500 \mathrm{~mL}$ septage recirculated over the cathode while $500 \mathrm{~mL}$ of a $10 \mathrm{mM}$ sodium sulfate solution was recirculated over the anode.

Batch tests. Batch tests were performed at constant current to investigate the charge needed to achieve a septage $\mathrm{pH}$ of $<3$ and $>9$ in the anode and cathode, respectively. In the first test $\left(A_{\text {batch }}\right), 500 \mathrm{~mL}$ septage and $500 \mathrm{~mL}$ of a $10 \mathrm{mM}$ sodium sulfate solution were recirculated through the anode chamber and cathode chamber, respectively (Fig. 4). In the next test $\left(C_{\text {batch }}\right), 500 \mathrm{~mL}$ septage and $500 \mathrm{~mL}$ of a $10 \mathrm{mM}$ sodium sulfate solution were circulated through the cathode chamber and anode chamber, respectively. The batch was run until the desired $\mathrm{pH}$ was reached and batch time for $A_{\text {batch }}$ and $C_{\text {batch }}$ was 80 and 30 min, respectively. Samples were collected for analysis at regular intervals. The circulation flow rates in all test were constant, mentioned previously. The current density range $A_{\text {batch }}$ and $C_{\text {batch }}$ was $7 \pm 1$ and $31 \pm 1 \mathrm{~mA} / \mathrm{cm}^{2}$, respectively.

In the second phase of batch electrolysis experiments, experiments were carried out at a constant voltage $\left(20 \mathrm{~V}, 8.7-12.7 \mathrm{~mA} / \mathrm{cm}^{2}\right)$. For a first test $\left(A C_{\text {batch }}\right), 6 \mathrm{~L}$ septage was recirculated $\left(0.48 \mathrm{~L} \mathrm{~h}^{-1}\right)$ by first passing through the anode chamber and then through the cathode chamber via a reservoir (working volume- $0.2 \mathrm{~L}$ ) (Fig. 5). The $\mathrm{pH}$ change of the anode chamber effluent and cathode chamber effluent was noted and samples of both effluents were collected at regular time intervals $(2 \mathrm{~h})$ and analyzed (COD, TKN, TAN, ortho-phosphate, and coliform). The duration of the batch was $14 \mathrm{~h}$. A similar experiment was repeated with septage $(0.7 \mathrm{~L})$ first passed through cathode and then through anode chamber via the reservoir at same recirculation rate $\left(0.48 \mathrm{~L} \mathrm{~h}^{-1}\right)$ and current density of $12.5 \mathrm{~mA} / \mathrm{cm}^{2}$ $\left(\mathrm{CA}_{\text {batch }}\right)$. The duration of a batch was $2 \mathrm{~h}$ and sampling done at every $15 \mathrm{~min}$.

Continuous experiments. In the next set of experiments, continuous electrolysis experiments were conducted. In the first continuous experiment $\left(A C_{\text {cont }}\right)$, septage was passed first through the anode chamber and then through the cathode chamber via reservoir (working volume- $0.1 \mathrm{~L}$ ) at $0.48 \mathrm{~L} \mathrm{~h}^{-1}\left(\mathrm{HRT}_{\mathrm{EC}}=0.42 \mathrm{~h}, \mathrm{HRT}_{\text {reservoir }}=0.2 \mathrm{~h}\right)$. Electrolysis carried out at 


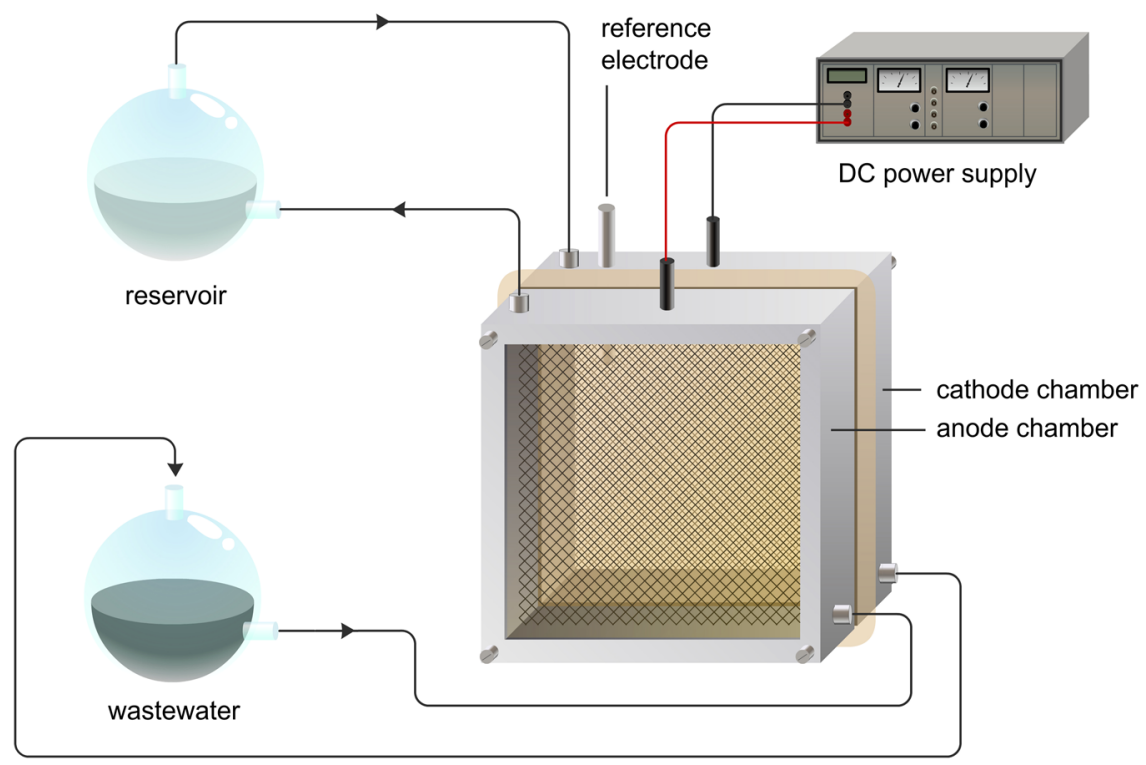

Fig. 5 Schematic diagram of setup showing flow path of the septage during experiment $A C_{b a t c h}$

constant current $\left(0.5 \mathrm{~A} ; 10.4 \mathrm{~mA} / \mathrm{cm}^{2}\right)$. Influent and effluent samples were collected at every $1 \mathrm{~h}$ for $9 \mathrm{~h}$ and analyzed for COD, TKN, TAN, orthophosphate, and coliform.

Continuous spiked septage experiments. In the next set of continuous experiments ( $\left.A C_{\text {cont-spiked }}\right)$, septage inoculated and incubated with pathogens (B. subtilis, E. coli, K. pneumoniae, S. aureus) prior to electrolysis was used as influent. To obtain the spiked septage, the culture was pregrown in specific media (Nutrient broth, EMB broth, MacConkey broth and Mannitol salt broth for B. subtilis, E. coli, K. pneumonia, and S. aureus, respectively) and incubated overnight at $37^{\circ} \mathrm{C}$ in a shaker. The $\mathrm{OD}_{600}$ of the culture was determined with spectrophotometer (Merck, Spectroquant Pharo 100), and used to adjust inoculum density to $5 \times 10^{9}$ cells $\mathrm{mL}^{-1}$. This spiked septage (containing single culture) was then subjected to electrochemical treatment. The effluent sample was collected at regular intervals and analyzed for colony count to determine disinfection. The samples collected were serially diluted in saline solution and spread plated on the agar plates with media specific to the culture. Non-diluted sample was also plated. After incubation, the plates were observed for the colonies and counted using colony counter. Independent experiments were conducted for each spiked septage. The experiment was repeated for electrolysis of septage spiked with $B$. subtilis at $\mathrm{HRT}_{\mathrm{EC}}=0.5$ and $0.8 \mathrm{~h}$. All spiked septage electrolysis carried out at $20 \mathrm{~V}$ constant voltage, variable current $0.3-0.7 \mathrm{~A}$ and flow rate $-0.48 \mathrm{~L} \mathrm{~h}^{-1}$.

Helminths experiment. The septic tank water was analyzed for helminths presence. Due to the low number of helminths in this wastewater, the eggs (Ascaris suum) were ordered from RTI International (NC, USA) and used to conduct the experiments to validate their inactivation by EC. The viability of the eggs was assessed before each experiment and characterized as potentially viable and non-viable. ${ }^{45}$ The $0.2 \mu \mathrm{l}$ egg suspension (approx. 100 eggs) was inoculated in anode effluent $(5 \mathrm{~mL} ; \mathrm{pH} 2.7)$ and cathode effluent $(5 \mathrm{~mL} ; \mathrm{pH} 10.4)$ obtained after electrolysis of septage at constant current $(0.6 \mathrm{~A})$. The $\mathrm{pH}$ of anode and cathode effluent after inoculation were 3.0 and 10.5 , respectively. The eggs were allowed to stay in the mentioned fluids for $10 \mathrm{~h}$. Sampling was done every hour and samples were observed microscopically for morphological changes in the eggs to qualitatively determine their viability. Tap Water was used as a control. The procedure was repeated with the septic tank water whose $\mathrm{pH}$ was adjusted to acidic (2.5) and alkaline (11) manually with $0.05 \mathrm{M} \mathrm{H}_{2} \mathrm{SO}_{4}$ and $0.1 \mathrm{M} \mathrm{NaOH}$ respectively and also septage added with hypochlorite disinfectant (household) at different concentrations and respective $\mathrm{pH}(0.02 \mathrm{M} ; 11.8$, $0.17 \mathrm{M} ; 12,0.34 \mathrm{M} ; 12.2,0.51 \mathrm{M} ; 12.4,0.68 \mathrm{M} ;>12.5,0.85 \mathrm{M}$; 13).

In another helminths experiment ( $\left.E C_{\text {helminths }}\right)$, septage spiked with helminths eggs was filled in the anode $(100 \mathrm{~mL})$ and cathode chamber $(100 \mathrm{~mL})$ of the lab scale EC and electrolyzed at constant current $(0.6 \mathrm{~A})$ for $30 \mathrm{~min}$. The sample from both the chambers were collected after electrolysis. Helminths eggs in the collected samples were extracted by

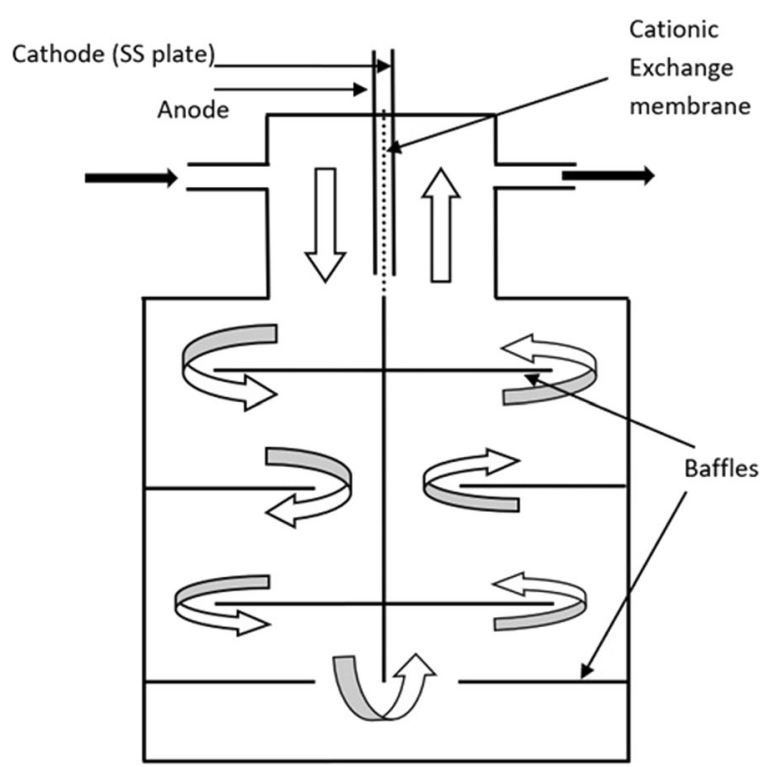

Fig. 6 Schematic cross-sectional diagram of the single household electrochemical reactor showing upper reactive cell, bottom holding tank with baffles, and the wastewater flow path

floatation/sedimentation method. Extracts containing eggs were allowed to stay for $10 \mathrm{~h}$ and observed every hour microscopically.

\section{Household scale treatment system}

A SHH treatment system was set up, consisting of a single toilet, septic tank $(1500 \mathrm{~L}), 2$ nd stage VFCW $\left(3 \mathrm{~m}^{2}\right.$ area), buffer tank $(1200 \mathrm{~L})$, and electrochemical reactor with buffer tank $(117 \mathrm{~L})$. The electrochemical reactor consisted of a cylindrical buffer tank $(100 \mathrm{~L})$ on top of which the EC was mounted. The same materials as previously were used for the electrodes and membrane $\left(30 \times 15 \mathrm{~cm}^{2}\right)$. The CEM was held by a frame built in within the reactor dividing the cell into 2 chambers of equal volume $(8.5 \mathrm{~L})$. Distance between the electrodes was $\leq 5 \mathrm{~mm}$. The cylindrical buffer tank had baffles that prevented dead pockets and water short-circuiting and ensured the stipulated retention of water (Fig. 6, SF5). The VFCW was designed according to the second stage of classical French two stage VFCW (Table 5, Figures SF6 and SF7). ${ }^{37}$ The wetland planted with Canna indica, was operated for 5 days prior to its integration to the $\mathrm{EC}$, 
Table 5. Filter media design details showing the size of particles for the vertical flow constructed wetland

Filter media (river gravels-three Layer depth $(\mathrm{m})$ Gravel size $(\mathrm{mm})$ layers)

\begin{tabular}{lll}
\hline Top layer & 0.4 & $0-4$ \\
Middle layer & $0.15-0.2$ & $4-10$ \\
Bottom layer & 0.2 & $10-20$ \\
\hline
\end{tabular}

during which septage was passed daily through the wetland $\left(0.2 \mathrm{~m}^{3}\right.$ day ${ }^{-1}$ approx.). The septage was distributed evenly over the wetland surface and allowed to percolate from the top to the bottom of the filter media, to allow the growth of the plants and to initiate the formation of microbial community in the upper layer of the filter media. The overall water flow path was from the toilet into the septic tank, into the VFCW, to the buffer tank, to the EC reactor and finally discharged for use.

Sampling was done before and after treatment (VFCW and EC) and analyzed. Electrolysis was carried out at constant current (average $=4.4 \mathrm{~A}$ ). Feed to the EC from the reservoir was intermittent, $7.5 \mathrm{~L} \mathrm{~h}^{-1}$ for $30 \mathrm{~min}$ in an hour with a peristaltic pump (NFP-03, Flowtech, India with flow rate range $0.8 \mathrm{~mL}$ to $3.6 \mathrm{~L} \mathrm{~min}^{-1}$ ) otherwise, at this small scale the pumps would suffer from clogging. The HRT in wetland and EC reactor was $6 \pm 2$ min and $15 \mathrm{~h}(2 \mathrm{~h}$ in EC, $13 \mathrm{~h}$ in buffer tank) respectively.

\section{Community scale treatment system}

A CS treatment system was a direct scale-up of the above mentioned SHH treatment system setup in BITS-Pilani Goa Campus premises, but with a considerably modified EC. The system consisted of a septic tank $\left(20 \mathrm{~m}^{3}\right)$, VFCW $\left(40 \mathrm{~m}^{2}\right.$ area), 2 reservoirs $\left(2 \mathrm{~m}^{3}\right.$ each), electrochemical reactor with holding tank (54 L EC $+1200 \mathrm{~L}$ ). The CS EC reactor was redesigned as a flat plate system with external holding tank/sump (Figure SF8 \& SF9). The EC consisted of three frames, two outer frames with one lateral side closed and one central frame with both lateral sides open. The central frame was sandwiched on either side by outer frames. Inner dimension of each chamber is $30(\mathrm{~L}) \times 7(\mathrm{~W}) \times 90(\mathrm{H}) \mathrm{cm}^{3}$. The central frame was separated from the outer two frames on its either side by CEM (Ultrex CMI7000, Membranes International Inc.) thereby creating three chambers (two outer anode chambers and one central cathode chamber) of internal dimension $30 \times 7 \times 90 \mathrm{~cm}^{3}$ giving volume of $18.9 \mathrm{~L}$ each. Every chamber had an inlet at the bottom and outlet at the top on opposite side walls of the frame. Total volume of the reactor was $54 \mathrm{~L}$. Two stainless steel plates $(29 \times$ $89 \mathrm{~cm}^{2}$, thickness $-1.5 \mathrm{~mm}$ ) in the central chamber and one IrOx MMO mesh $\left(29 \times 89 \mathrm{~cm}^{2}\right.$, thickness $\left.-1.5 \mathrm{~mm}\right)$ in each outer chamber formed the cathode and anode electrode, respectively. The sump/holding tank which was connected through piping to the main EC is a simple baffled rectangular tank $(1200 \mathrm{~L})$ that ensures retention of water for a stipulated time in the holding tank (Figure SF8).

The explained system was connected to two blocks of toilets (24 toilets in total) in the male student hostel located within the BITS-Pilani Goa Campus. The wetland was operated 1 month prior to its integration to the CS EC reactor. The system was run continuously $\left(1.5 \mathrm{~m}^{3} /\right.$ day $)$ with induction motor pump with manual flow rate control and sampling was done after every stage in the treatment system, EC was run in constant current mode (average $=30 \mathrm{~A}$ ). Sampling was done once in 3 days for 60 days. The wetland was never backwashed for both the integrated systems (SHH and CS).

\section{Data availability}

All data generated and analyzed during this present study are included in this article (and its supplementary information file).

\section{ACKNOWLEDGEMENTS}

This research was supported and funded through the project named "Empowered Septic Tank as decentralized wastewater treatment system" under "Reinvent the toilet challenge" initiative by DBT-BIRAC and Bill \& Melinda Gates Foundation. The authors also greatly acknowledge the support of BITS-Pilani K.K. Birla Goa Campus, for providing site for household scale and community scale treatment system setup.
Acknowledgement to Tim Lacoere (Technician, CMET, Ghent University) for the schematic drawings, Stephen J. Andersen (Post-doctoral researcher, CMET, Ghent University), a native English speaker, for reviewing and editing the manuscript and also to Mr. Mahaling Lamani for his labor and services for maintenance of the treatment system.

\section{AUTHOR CONTRIBUTIONS}

G.V.T. is the co-first author. G.V.T. and P.S. completed all the lab scale experiments, analysis, manuscript writing. P.S. and A.Y. performed helminths analysis. G.V.T. and A. $Y$. contributed to the design of the reactors and monitoring fabrication of reactors and setup of the treatment systems. A.Y. contributed on the design of VFCW. K.R. designed the reactors and provided technical support throughout. M.S. contributed on the design of the experiments and supported us with his expertise throughout the study. P.C. provided technical feedback during the laboratory scale experiments and was involved in editing and revising the manuscript critically in preparation for submission. All authors read and approved the final manuscript.

\section{ADDITIONAL INFORMATION}

Supplementary information accompanies the paper on the npj Clean Water website (https://doi.org/10.1038/s41545-018-0014-x).

Competing interests: The authors declare no competing interests.

Publisher's note: Springer Nature remains neutral with regard to jurisdictional claims in published maps and institutional affiliations.

\section{REFERENCES}

1. CPCB ENVIS Letter. Wastewater Generation \& Treatment: Domestic Sewage Urbanisation \& Wastewater Management in India (2000).

2. UNICEF \& WHO. 2015 Update and MDG Assessment (2015).

3. Showkat, N. Coverage of sanitation issues in India. SAGE Open. 6, https://doi.org/ 10.1177/2158244016675395. (2016)

4. Kumar, G. S., Jain, A. \& Kar, S. S. Health and environmental sanitation in India: issues for prioritizing control strategies. Indian J. Occup. Environ. Med. 15, 93 (2011).

5. Vymazal, J. Constructed wetlands for wastewater treatment: five decades of experience. Environ. Sci. Technol. 45, 61-69 (2010).

6. Neralla, S., Weaver, R. W., Lesikar, B. J. \& Persyn, R. A. Improvement of domestic wastewater quality by subsurface flow constructed wetlands. Bioresour. Technol. 75, 19-25 (2000).

7. Weber, K. P. \& Legge, R. L. Pathogen Removal in Constructed Wetlands. Wetlands: Ecology, Conservation \& Restoration, Ch. 5 (Nova Science Publishers, 2008).

8. Zurita, F. \& White, J. R. Comparative study of three two-stage hybrid ecological wastewater treatment systems for producing high nutrient, reclaimed water for irrigation reuse in developing countries. Water 6, 213-228 (2014).

9. Sayadi, M. H., Kargar, R., Doosti, M. R. \& Salehi, H. Hybrid constructed wetlands for wastewater treatment: a worldwide review. Proc. Int. Acad. Ecol. Environ. Sci. 2, 204-222 (2012).

10. Tyrrell, S. A., Rippey, S. R. \& Watkins, W. D. Inactivation of bacterial and viral indicators in secondary sewage effluents, using chlorine and ozone. Water Res. 29, 2483-2490 (1995).

11. Macauley, J. J., Qiang, Z., Adams, C. D., Surampalli, R. \& Mormile, M. R. Disinfection of swine wastewater using chlorine, ultraviolet light and ozone. Water Res. 40, 2017-2026 (2006)

12. Kraft, A. Electrochemical water disinfection: a short review. Platin. Met. Rev. 52, 177-185 (2008).

13. Huang, X. et al. Electrochemical disinfection of toilet wastewater using wastewater electrolysis cell. Water Res. 92, 164-172 (2016).

14. Naje, A. S. \& Abbas, S. A. Combination of electrocoagulation and electro-oxidation processes of textile wastewaters treatment. Civil Environ. Res. 3, 61-74 (2013).

15. Costa, C. R., Botta, C. M. R., Espindola, E. L. G. \& Olivi, P. Electrochemical treatment of tannery wastewater using DSA electrodes. J. Hazard. Mater. 153, 616-627 (2008).

16. Szpyrkowicz, L., Kelsall, G. H., Kaul, S. N. \& De Faveri, M. Performance of electrochemical reactor for treatment of tannery wastewaters. Chem. Eng. Sci. 56, 1579-1586 (2001)

17. Vlyssides, A. G., Loizidou, M., Karlis, P. K., Zorpas, A. A. \& Papaioannou, D. Electrochemical oxidation of a textile dye wastewater using a $\mathrm{Pt} / \mathrm{Ti}$ electrode. J. Hazard. Mater. 70, 41-52 (1999).

18. Grimm, J., Bessarabov, D. \& Sanderson, R. Review of electro-assisted methods for water purification. Desalination 115, 285-294 (1998). 
19. Hong, K. H. et al. Characteristics of organics and nutrients removal in municipal wastewater treatment by electrolysis using copper electronic conductor. Int. J. Electrochem. Sci. 9, 3979-3989 (2014).

20. Yun, C. Y. et al. Application and assessment of enhanced electrolytic process for laundry wastewater treatment. Int. J. Electrochem. Sci. 9, 1522-1536 (2014).

21. Tartakovsky, B., Mehta, P., Bourque, J. S. \& Guiot, S. R. Electrolysis-enhanced anaerobic digestion of wastewater. Bioresour. Technol. 102, 5685-5691 (2011).

22. Feng, C., Sugiura, N., Shimada, S. \& Maekawa, T. Development of a high performance electrochemical wastewater treatment system. J. Hazard. Mater. 103, 65-78 (2003).

23. Tennakoon, C. L. K., Bhardwaj, R. C. \& Bockris, J. O. Electrochemical treatment of human wastes in a packed bed reactor. J. Appl. Electrochem. 26, 18-29 (1996).

24. Feng, Y., Yang, L., Liu, J. \& Logan, B. E. Electrochemical technologies for wastewater treatment and resource reclamation. Environ. Sci. Water Res. Technol. 2, 800-831 (2016)

25. Vlyssides, A. G., Karlis, P. K., Rori, N. \& Zorpas, A. A. Electrochemical treatment in relation to $\mathrm{pH}$ of domestic wastewater using Ti/Pt electrodes. J. Hazard. Mater. 95 , 215-226 (2002).

26. Sarkka, H., Bhatnagar, A. \& Sillanpaa, M. Recent developments of electrooxidation in water treatment-a review. J. Electroanal. Chem. 754, 46-56 (2015).

27. Jeong, J., Kim, C. \& Yoon, J. The effect of electrode material on the generation of oxidants and microbial inactivation in the electrochemical disinfection processes. Water Res. 43, 895-901 (2009)

28. Maris, P. Modes of action of disinfectants. Rev. Sci. Tech. Off. Int. Epiz. 14, 47-55 (1995).

29. Kraft, A. et al. Electrochemical water disinfection. Part I: hypochlorite production from very dilute chloride solutions. J. Appl. Electrochem. 29, 861-868 (1999).

30. Krstajić, N., Nakić, V. \& Spasojević, M. Hypochlorite production II. Direct electrolysis in a cell divided by an anionic membrane. J. Appl. Electrochem. 21, 637-641 (1991).

31. Desloover, J., Woldeyohannis, A. A., Verstraete, W., Boon, N. \& Rabaey, K. Electrochemical resource recovery from digestate to prevent ammonia toxicity during anaerobic digestion. Environ. Sci. Technol. 46, 12209-12216 (2012).

32. Kim, K. W., Kim, Y. J., Kim, I. T., Park, G. I. \& Lee, E. H. The electrolytic decomposition mechanism of ammonia to nitrogen at an $\mathrm{IrO}_{2}$ anode. Electrochim. Acta 50, 4356-4364 (2005)

33. Li, L. \& Liu, Y. Ammonia removal in electrochemical oxidation: mechanism and pseudo-kinetics. J. Hazard. Mater. 161, 1010-1016 (2009).

34. Wahyuni, E. A. The influence of $\mathrm{pH}$ characteristics on the occurance of coliform bacteria in Madura Strait. Procedia Environ. Sci. 23, 130-135 (2015).

35. Lee, J. K., Movahedi, S., Harding, S. E. \& Waites, W. M. The effect of acid shock on sporulating Bacillus subtilis cells. J. Appl. Microbiol. 94, 184-190 (2003).

36. Mitsuhashi, T., Ishida, Y., Kadota, H. \& April, A. pH-temperature effects on swelling of spores during germination. Bull. Jpn. Soc. Sci. Fish. 51, 1723-1726 (1985)
37. Paing, J., Guilbert, A., Gagnon, V. \& Chazarenc, F. Effect of climate, wastewater composition, loading rates, system age and design on performances of French vertical flow constructed wetlands: a survey based on 169 full scale systems. Ecol. Eng. 80, 46-52 (2015).

38. Lee, C., Fletcher, T. D. \& Sun, G. Nitrogen removal in constructed wetland systems Eng. Life Sci. 9, 11-22 (2009).

39. Horn, T. B., Zerwes, F. V., Kist, L. T. \& Machado, Ê. L. Constructed wetland and photocatalytic ozonation for university sewage treatment. Ecol. Eng. 63, 134-141 (2014).

40. La Motta, E. J. \& Acosta, J. Electro-disinfection of municipal wastewater: laboratory scale comparison between direct current and alternating current. Int. J. Eng. Res. Appl. 1, 06-12 (2017).

41. Jasper, J. T., Yang, Y. \& Hoffmann, M. R. Toxic byproduct formation during electrochemical treatment of latrine wastewater. Environ. Sci. Technol. 51, 7111-7119 (2017).

42. American Public Health Association (APHA). Standard Methods for the Examination of Water and Wastewater 21st edn (American Water Works Association \& Water Environment Federation, 2005).

43. Moodley, P., Archer, C. \& Hawksworth, D. Standard Methods for the Recovery and Enumeration of Helminth Ova in Wastewater, Sludge, Compost and Urine-diversion Waste in South Africa: Report to the Water Research Commission (2008).

44. Rabaey, K., Lissens, G. \& Verstraete, W. Microbial Fuel Cells: Renewable Energy From Biomass Fermentation, 377-399 (2005).

45. De Victorica, J. \& Galván, M. Preliminary testing of a rapid coupled methodology for quantitation/viability determination of helminth eggs in raw and treated wastewater. Water Res. 37, 1278-1287 (2003).

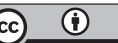

Open Access This article is licensed under a Creative Commons Attribution 4.0 International License, which permits use, sharing, adaptation, distribution and reproduction in any medium or format, as long as you give appropriate credit to the original author(s) and the source, provide a link to the Creative Commons license, and indicate if changes were made. The images or other third party material in this article are included in the article's Creative Commons license, unless indicated otherwise in a credit line to the material. If material is not included in the article's Creative Commons license and your intended use is not permitted by statutory regulation or exceeds the permitted use, you will need to obtain permission directly from the copyright holder. To view a copy of this license, visit http://creativecommons. org/licenses/by/4.0/.

(c) The Author(s) 2018 